\title{
Editorial: The Brazilian society of food science and technology has a new board
}

Dear Readers,

The new Board of the Brazilian Society for Food Science and Technology was elected on the 29 January 2012 for 2013-2014. The Board is composed of Narendra Narain (president); Felix Guillermo Reyes Reyes (first vice-president); Amaury Rosenthal (second vice-president); Maria Lucia Nunes (third vice-president); Paulo Eduardo da Rocha Tavares (secretary); Kátia Maria Vieira Avelar Bittencourt Cipolli (deputy secretary); Silvia Pimentel Marconi Germer (financial director); Regina Kitagawa Grizotto (deputy financial director); Nilson Evelázio de Souza (director for publications); Eliana Badiale Furlong (deputy director for publications); Deborah Helena Markwicz (director for propaganda); Valéria Paula Rodrigues Minim (public relations officer); Susana Cardoso (director for Conferences and Scientific Events); Walter Augusto Ruiz (director for courses); José Ricardo Bessa de Carvalho (director for industrial relations); Maria Inês Sucupira Maciel (deputy director for industrial relations) and Bruno Chacon de Figueiredo (director for student relations).

Chief Editor and Vice-Editor for the 2011 and 2012 scientific journal Food Science and Technology were Mirna Gigante (UNICAMP) and Virginia Martins da Matta (EMBRAPA), with the important collaboration of the following Associated Editors: Célia Maria Landi Franco (UNESP), Fabio Yamashita (UEL), Rafaella Andrade Mattietto (EMBRAPA), Suely Pereira Freitas (UFRJ) and Neura Bragagnolo (UNICAMP) (Supplement 2012).

Chief Editor and Vice-editor for 2013-2014 will be Nilson Evelázio de Souza (UEM/UTFPR) and Eliana Badiale Furlong (FURG), with the collaboration of the following Associated Editors: Raimundo Wilane de Figueiredo (UFC), Valéria Paula Rodrigues Minim (UFV), Neura Bragagnolo (UNICAMP); Alexandre da Trindade Alfaro (UTFPR) and Helena Teixeira Godoy (UNICAMP).

Funding for 2013 has been guaranteed by Conselho Nacional de Desenvolvimento Científico e Tecnológico (CNPq) with R $\$ 20.000,00$ as a result of a Project coordinated by Mirna Gigante and approved by MCTI/CNPq/MEC/CAPES-2011. We will also forward a project to FAPESP in 2013 so the publication of the journal in all its stages in formatting, text revision, normalization and printing may occur without any financial difficulties.

The Qualis/CAPES (Coordenação de Aperfeiçoamento de Pessoal de Ensino Superior) grades for 2010-2012 were attributed as follows: B1: Engineering I, Engineering II, Interdisciplinary, Agrarian Sciences I, B2: Food Science, Veterinary Medicine, Animal Science/Fishing Resources, Biodiversity, B3: Pharmacy, Community Health, B4: Chemistry and Biotechnology. It is our aim to improve the above grades for 2013-2015. Correspondence has been maintained with Dra. Maria Beatriz Abreu Glória (UFMG, CAPES) so that a QUALIS upgrade could be obtained for the Post-graduate Programs in Food Science and Technology, and thus a greater valorization for the journal of the Sociedade Brasileira de Ciência e Tecnologia de Alimentos.

According to SCOPUS, the visibility of the journal Ciência e Tecnologia de Alimentos obtained a Source Normalized Impact per Paper (SNIP) of 0.057 in 2007; 0.248 in 2008, 0.424 in 2009, 0.462 in 2010 and 0.476 in 2011. Citations in SCOPUS amounted to 103 in 2008; 223 in 2009; 359 in 2010 and 526 in 2011, with as highly probable SNIP increase for 2012. In the case of SCImago Journal Rank (SJR), it reached 0.125 in $2007,0.167$ in 2008, 0.231 in 2009, 0.240 in 2010 and 0.275 in 2011, with constant growth. Another highly relevant indexing mark is ISI WEB KNOWLEDGE with 109 citations in 2009; 194 in 2010; 324 in 2011 and 353 in 2012, with a sharp increase in ISI citations. Journal Citation Reports (JCR) featured 0.266 in 2010 and 0.221 in 2011, with a higher rate for 2012, according to the growing number of citations in ISI.

A greater visibility for the journal Food Science and Technology has been the main feature when it started to be published entirely in English.

The SBCTA Board in its meeting on the $30^{\text {th }}$ January 2013 unanimously approved the changed of the review's title "Ciência e Tecnologia de Alimentos" to another one in English.

After receiving many suggestions, the SBCTA Board will approve a new title for the journal during an ordinary session of the Society.

Nilson Evelazio de Souza

Chief Editor of the Ciência e Tecnologia de Alimentos

Eliana Badiale Furlong

Deputy Editor of the Ciência e Tecnologia de Alimentos 